\title{
Marine Environment around Taiwan Coast
}

\author{
Ho-Shong Hou \\ Graduate School of Civil and Ecological Engineering, I-Shou University, Kaohsiung, Taiwan, R.O.C.
}

\begin{abstract}
Coastal erosion is an island-wide problem in Taiwan; about $80 \%$ of the island's sandy coastline had suffered from erosion over the past few decades. Historically, with the specific tectonic environment and rapid uplifting rate, lots of sediment had been yielded and transported to the coastal area that resulted in an advancing shoreline. Taiwan economically moved from a developing country to a developed one; a lot of human intervention had been made along the island coast. These are the major factors on recent coastal erosion. Even actions such as building of stabilization structures may inadvertently increase erosion. Some intervention examples are chosen to address how human-induced change made the profound impact on coastal erosion in Taiwan. All the information serves to provide a better understanding of the coastal processes, and a better response to the erosion problem.
\end{abstract}

Key words: Erosion, sediment, protection construction.

\section{Introduction}

Taiwan is an island formed from the tectonic activities in the circum-Pacific belt. The mountain building process is still active with a rapid uplifting rate. Due to this mountain building process, lots of sediments had been yielded and transported to the coastal area, which resulted in an advancing shoreline. Based on the most recent survey, about $80 \%$ of the island's sandy beach had suffered from erosion over the past few decades (Fig. 1), and coastal erosion has become an island-wide problem in Taiwan. Taiwan has a land area of $36,000 \mathrm{~km}^{2}$, and a total shoreline length of $1,600 \mathrm{~km}$. The shoreline/land area ratio is $44.4 \mathrm{~m} / \mathrm{km}^{2}$, which is about 2.4 times as large as USA and is half of Japan. Since mountain areas account for about three-fifth of Taiwan, most of the population is concentrated along the coastal regions. During the recent processes that change Taiwan economically from a developing country to a developed one, a lot of human intervention had been made along the island coast, and are the major factors that cause significant impact on recent coastal erosion.

Corresponding author: Ho-Shong Hou, Ph.D., professor, research fields: coastal, hydraulic and harbor engineering.

\section{Coastal Erosion Resulting from Human Activities}

Coast is a dynamic system that shorelines and beaches are subject to continual change. Diverse and complex natural processes, such as waves, tides, currents and winds continually change coast and attempt to achieve a dynamic balance of coast. Human activities cause coastal alternation by modifying and disturbing the coastal environments and the natural processes of change. A sediment budget model is usually used to elucidate coastal erosion within a specified compartment. If the sum of sediment inflow rates is smaller than that of outflows, the coast tends to erode and vice versa. Human activities that interrupt natural sediment movements have direct or indirect effects on the changing coasts. They may affect sources of new sediment to the coast or promote the land subsidence or relative sea-level rise locally. Human-induced causes of coastal erosion in Taiwan may include reduction of sediment supply from rivers, construction of improper engineering structures and the land subsidence due to over extraction of ground water.

\section{Reduction of Sediment Supply from Rivers}

Fluvial sediments are the most important sediment sources for the western coast of Taiwan. Most rivers in 


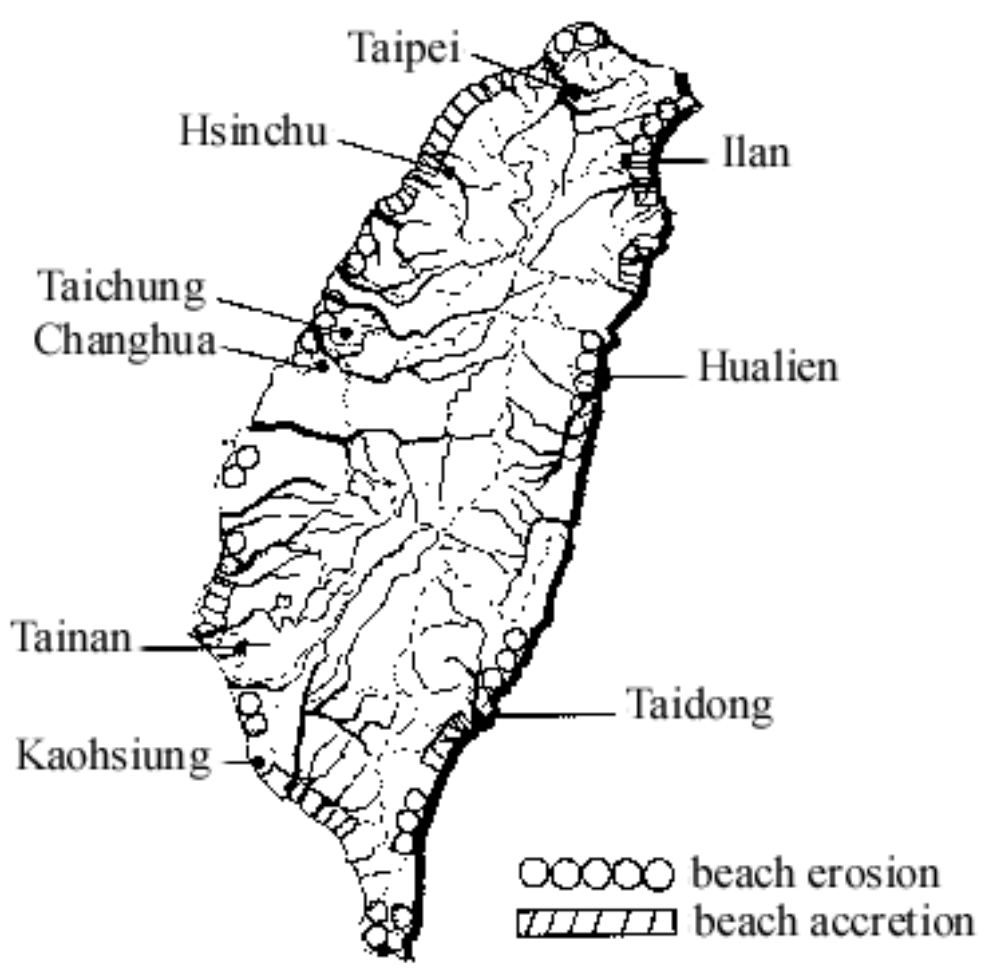

Fig. 1 Spatial diversity of beach erosion along Taiwan Coast.

Source: Refs. [4, 5].

Taiwan are mountainous rivers that are short and steep. The river flows show distinctively dry and flood seasons. The sediment discharges to the river mouths mainly take place in flood season, especially during a typhoon or rainy storm events. During dry season, the sediments are re-distributed by coastal processes, such as waves, tides, currents and winds to form wide beaches and dune fields along the western coast of Taiwan.

\section{River Improvement}

The Taipei basin, where Taipei City is situated, was produced as an alluvial plain of the Tanshui. A wide beach was fanned by voluminous depositional materials discharged through the river mouth. The sediment transport is downcoast to the south. Several rows of sand dunes were developed along the coastal line. The Taipei basin has traditionally been one of the important administrative areas in Japan and has suffered flood damage for several decades; now it is solved by MOEA (Ministry of Economic Affairs).
In order to prevent flood damage, the flood channel project was initiated in 1970s by the government. The construction project was finished in the 1980s and many difficulties had been overcome. In connection with this flood channel flood work, groins were gradually extended to the sea around the river mouth to trap littoral drift.

Both projects were quite successful in achieving the disaster prevention purpose, but they also brought beach erosion at Linco and Bali Coast that was located at the south of the Tanshui River. The completion of this project resulted in the rapid beach erosion along the Linco and Bali Coast. The shoreline retreats at a speed of $8 \mathrm{~m} /$ year and is steadily eroded in the south region and the downward side (south) of the Taipei Port.

\section{Construction of Reservoir}

Building a reservoir in the middle reach of Tseng-wen River is the other example to result in the coastal erosion at the river mouth. The reservoir was 


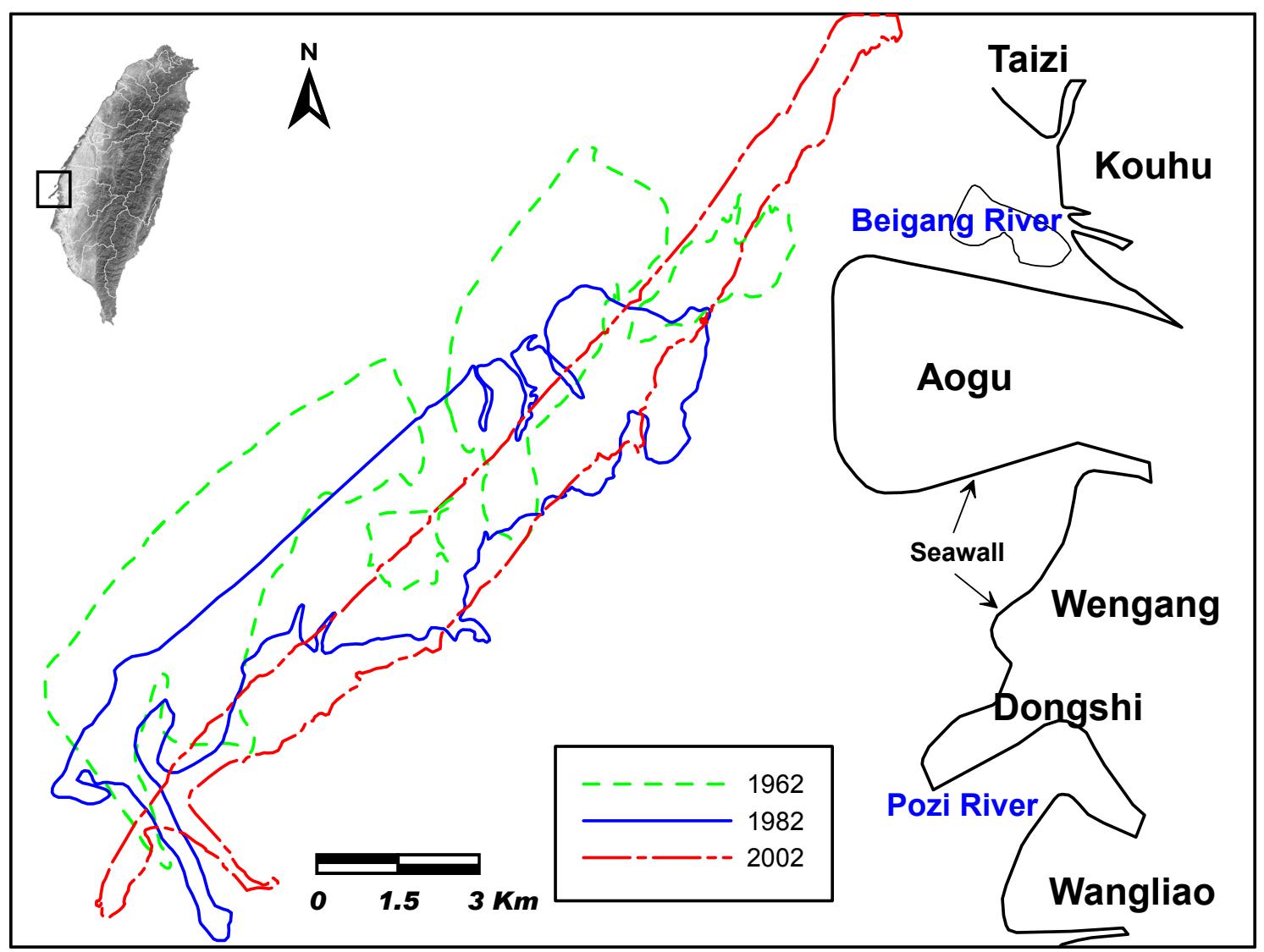

Fig. 2 Historical evolution of Waisanding barrier.

built to supply water for multiple uses such as agriculture and the power plant, but shoreline retreated around the mouth of Tseng-wen River, is a kind of beach erosion.

Dam or reservoir construction on the major river could cut off its sediment supply to the coast and can produce a significant imbalance in the budget of littoral sediments, leading to major beach erosion. The most extreme example of this has been the construction of a reservoir in the middle reach of the Tsengwen River in 1973. The completion of the Tsengwen reservoir blocked approximately $99 \%$ of the river's sediment supply to the coast, resulting in large-scale shoreline erosion.

Tsengwen River has a total length of $138.47 \mathrm{~km}$ and a drainage area of $1,176.64 \mathrm{~km}^{2}$. The reservoir contains a drainage area of $481 \mathrm{~km}^{2}$ and capacity of 7.08 billion $\mathrm{m}^{3}$; it was built to supply water for multiple uses, such as agriculture irrigation, power plant and people use (drinking, etc.).

\section{Over-mining of Riverbeds}

In addition, due to the shortage of sand/gravel resources on land, a large amount of sand/gravel was mined either legally or illegally from the riverbed to be utilized as the concrete material in construction structures. All these activities cause the reduction of sediment supply from rivers. Examples for the over-mined riverbeds are from Chou-Shui River and Lanyang River. Wai San Ding barrier is an island located at the south of Chou-Shui River mouth, and is thought to be the sink of the discharging sediments from the Chou-Shui River. With the huge amount of sediment mining from the riverbed at the lower reach of the river, the Wai San Ding barrier has been shrinking, such that shorelines on both ocean side and lagoon side are retreating. The total area of the barrier island has been gradually reduced (Fig. 2).

Dune erosion along the sandy coast of I-Lan is the 


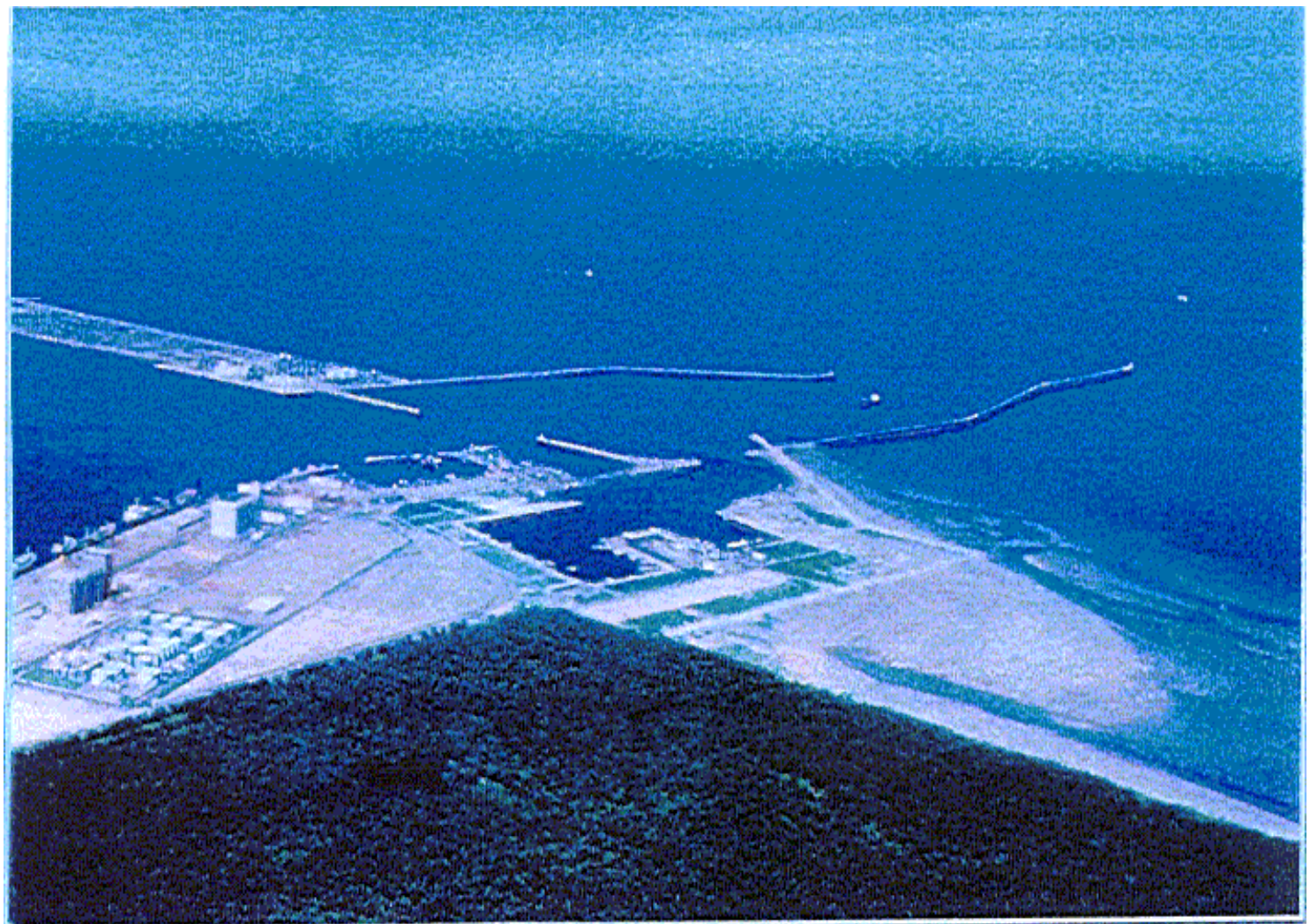

(a)

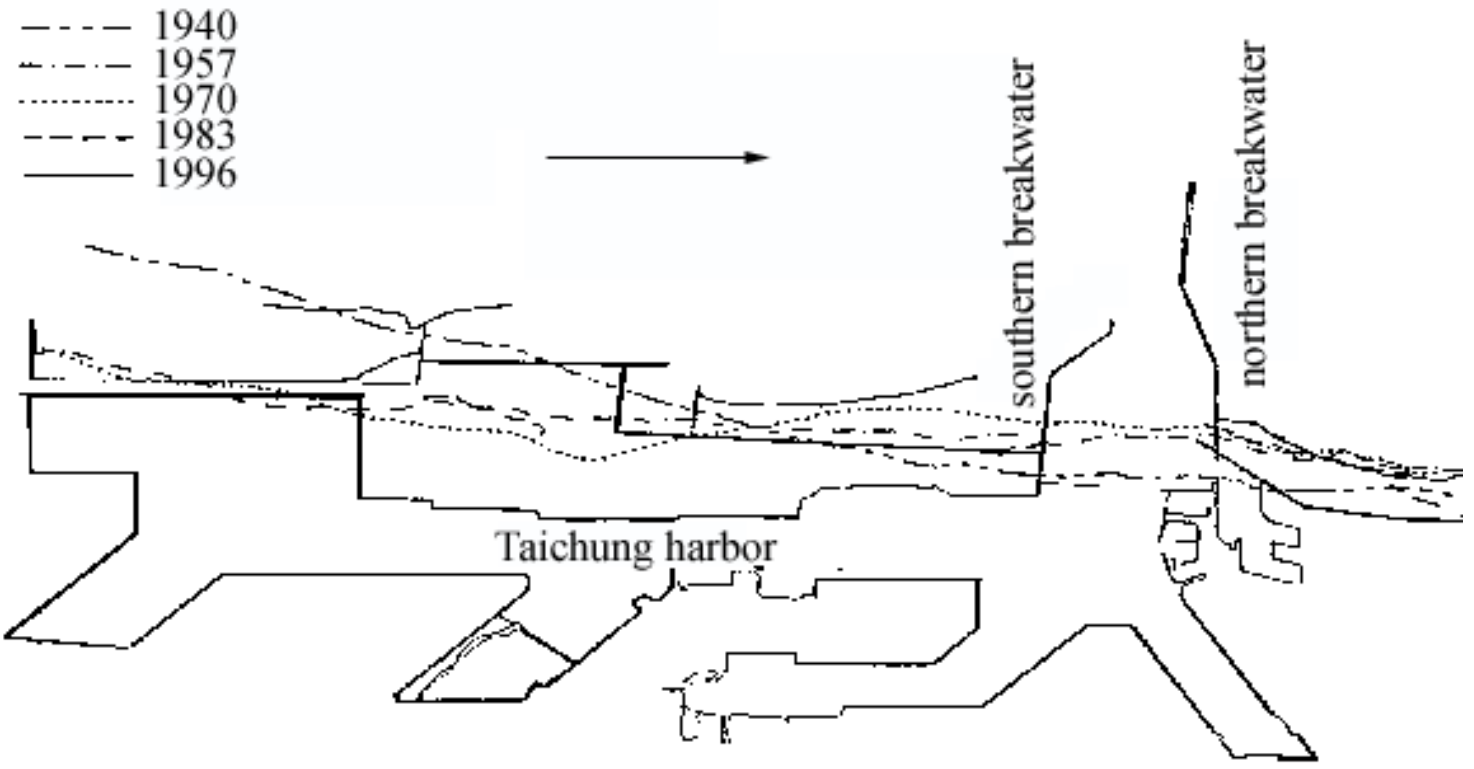

(b)

Fig. 3 Littoral drift deposit along north breakwater: (a) the northern breakwater at Taichung harbor, with sand accretion on the updrift side and erosion on the downdrift side; (b) shoreline changes resulting from the construction of the northern breakwater at Taichung harbor, with extreme erosion on the downdrift side.

Source: Refs. $[1,2,6]$. 
other example of sediment over-mined on riverbed. Coastal sediments along the sandy coast of I-Lan are mainly from the sediment yielded by the Lanyang River. Without a proper regulation to restrict sediment mining from the riverbed, the annual inputs of river sediment to the littoral system are far less than it used to be, and beach/dune erosion had occurred.

\section{Construction of Improper Engineering Structures}

Coastal erosion could be also due to the improper construction of engineering structures along the coast. Structures such as breakwaters, jetties and groins tend to block the longshore sediment transport or change the nearshore current system. Shore-parallel structures like seawalls tend to intensify wave energy due to strong wave reflection.

One example here is the construction of Taichung commercial harbor along the Wuchi Coast. The far extension of the northern breakwater at Taichung harbor had blocked the longshore sediment transport that moved sediments from north to the south. This interruption of longshore sediment transport has caused sediment accumulation on the updrift side of the breakwater and led to severe coastal erosion on the downdrift side 1,500 m south (Figs. 3a and 3b).

The extended breakwater could reduce the wave heights in the harbor's lee marine area by providing effective sheltering protection as it was designed for. However, it also results in changes of the nearshore current system and sediment transport. Hommei fishery port at Taipei County is another example that had its northern breakwater extended to about $200 \mathrm{~m}$ long in 1984 to protect the port from wave attacks. However, the extension of breakwater had caused the siltation (accumulation of fine sediments) in the lee side of the port and the rapid beach erosion along the Jinsawan Coast, a beautiful recreation beach that was just next to the port at the south (Fig. 4). However, the reversed currents induced by the sheltering of the extended breakwater carry the sediments from Jinsawan towards the entrance of the port. It is noticed that an additional northern current is generated along the Jinsawan Coast due to changes of radiation stresses and wave patterns.

Beach usually acts as a buffer to waves and storm surges. Construction of the seawalls, especially the vertical seawalls, has the tendency to destroy the fronting beaches and result in beach erosion. One example of the vertical seawall is at the Golden Coast in Tainan City. The 150-meter wide fronting beach was destroyed and became very narrow during the Typhoon Herb event in 1996. Shoreline receded about $80 \mathrm{~m}$ after the event. The vertical seawalls reflected the normal waves back to the sea during storms and these reflected waves could double the energy to the seabed that normally cause coastal erosion. When incident and reflected waves are oblique to the wall, they set up a short-crested system that moves sediment downdrift and leads to bed scouring.

\section{Land Subsidence}

The total number of fishing farms along Taiwan Coast has steadily grown since the 1970s. Large amounts of ground water are extracted to mix with seawater for aqua-cultural farming. The over pumping of ground water is lowering the water table and reducing the pore pressure within the subsurface layer. This permits compaction of the subsurface layer and produces the subsidence. With the land subsidence, shoreline will retreat.

Wenfong Coast (Fig. 5) of Ping-Tung County, is an example of shoreline retreat due to land subsidence by the over pumping of ground water. The subsidence rate reached a maximum value of $1,000 \mathrm{~mm}$ per year. The accumulated subsidence reaches more than $1 \mathrm{~m}$ at some places. Such large-scale subsidence extends to the sea bottom and hence accelerates beach erosion. Shoreline recedes by about $80 \mathrm{~m}$ within 11 years (1972 1983). The coast is always exposed to coastal hazards in many typhoon events. The 
seawall was built in 1980 s to prevent the storm wave attacks on the subsiding coast. In just a few years, the fronting beach had disappeared, and the seawall also subsided. Without much success of the seawall, eight segments of breakwaters are constructed about $100 \mathrm{~m}$ offshore in 1984 to provide protection of the present seawalls (Fig. 5).

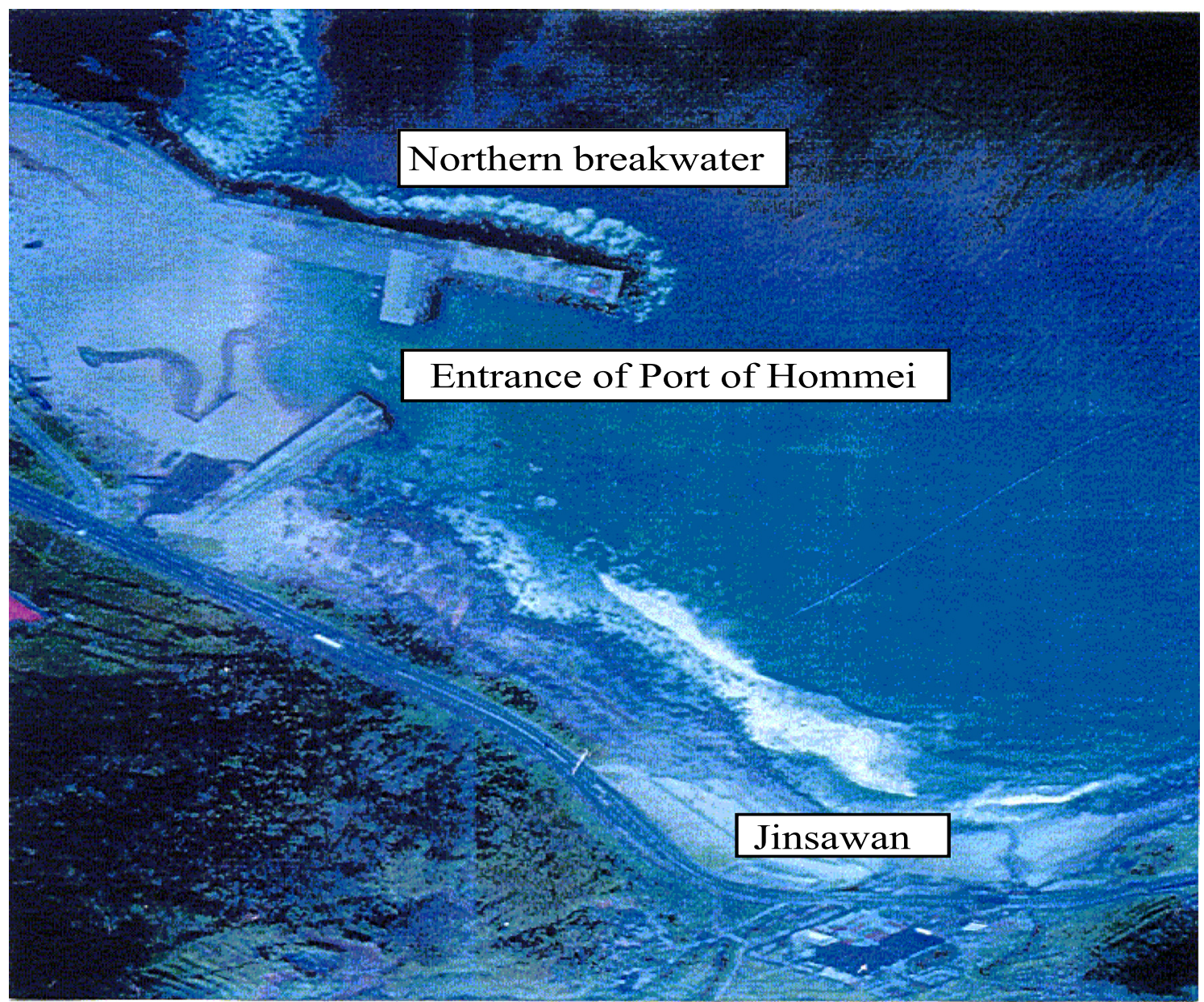

Fig. 4 Sand deposition in the sheltered lee of the extended northern breakwater at port of Hommei and erosion of Jinsawan Coast.

Source: Ref. [3].

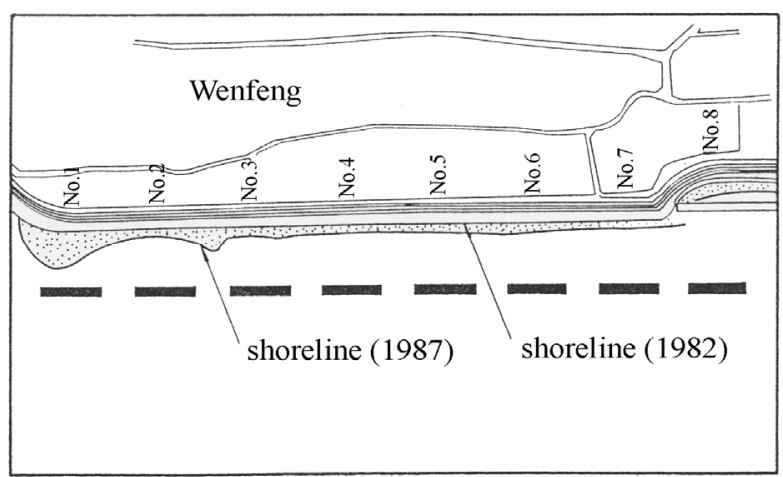

(a)

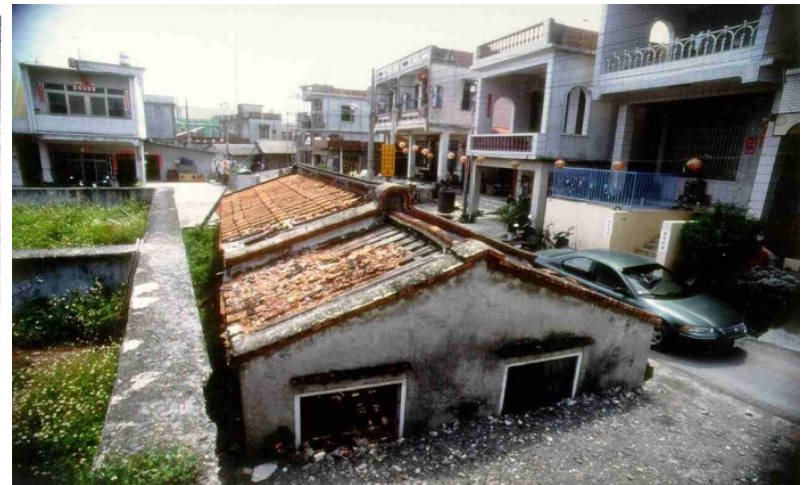

(b)

Fig. 5 Land subsidence and shoreline retreat at Wenfong Coast: (a) shoreline retreat; (b) land subsidence. 


\section{Conclusions}

Coastal erosion is presently a serious problem in Taiwan, and coastal protection is becoming a major expense. Based on the examples discussed, it is obvious that even engineering structures designed to stabilize the shoreline, can inadvertently increase erosion. Therefore, a good understanding of the physical nature of the problem is necessary before any solution is considered. With very limited living space in Taiwan, coastal development is an irreversible trend. The experiences provided in this paper should enable all future developers with better assessment, planning and management in terms of sustainable development. Since coastal processes and erosion problems are very site specific, cooperative scientific investigation of the coastal system around Taiwan is not only necessary, but also urgent to provide the crucial information needed to minimize the unintended effects of human disturbances along the Taiwan Coast.

\section{Reference}

[1] Hou, H.-S. 1974. "Research on the Model Sheltering Investigation on a Harbor." In Proceedings of the 14th International Coastal Engineering Conference, 2139-66.

[2] Hou, H.-S., Christensen, B. A., and Chiu, T. Y. 1975. "Movable Bed Model Investigation of Taichung Harbor, Taiwan, ROC." In Proceedings of Symposium on Modeling Techniques, Modeling 75, 2nd Annual Symposium of the Waterways, Harbors and Coastal Engineering, 974-92.

[3] Hou, H.-S., and Christensen, B. A. 1976. "The Influence of Equivalent Sand Roughness on the Dispersion Coefficient in Laboratory and Natural Streams." In Proceedings of Symposium on Inland Waterways for Navigation, Flood Control, 1179-98.

[4] Hou, H.-S., and Hsu, T. W. 2000. "An Overview of Coastal Erosion along Taiwan Coast." Presented at 27th International Conference on Coastal Engineering Sydney, Australia, 2000.

[5] Hou, H.-S., and Hou, P.-H. 2016. "Ocean Energy of Taitung Coast in Taiwan." Presented at International Conference of Coastal Zone, Osaka, Japan, 2016.

[6] Hou, H.-S., ed. 2005. Planning and Design of Coastal and Harbour Engineering. Taichung, Taiwan, R.O.C.: Jin-Yu-Tan Publishing Co. 